\title{
Perception and Adaptation Strategies of Dairy Farmers Towards Climate Variability and Change in West Africa
}

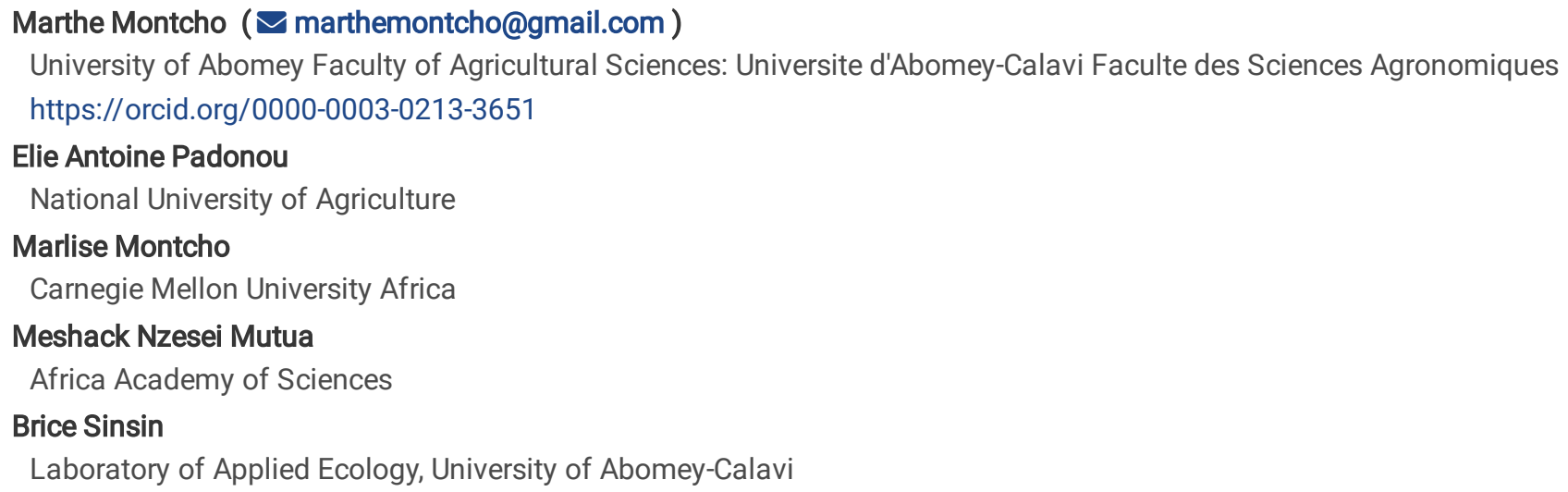

Research Article

Keywords: Milk, dairy farmers, climate change, adaptation strategies, typology, West Africa

Posted Date: June 28th, 2021

DOI: https://doi.org/10.21203/rs.3.rs-615302/v1

License: (c) (1) This work is licensed under a Creative Commons Attribution 4.0 International License. Read Full License

Version of Record: A version of this preprint was published at Climatic Change on February 1st, 2022. See the published version at https://doi.org/10.1007/s10584-022-03311-4. 


\section{Abstract}

In West Africa, dairy production plays a vital role in the economy and the wellbeing of the population. Currently, dairy production has become vulnerable due to climate variability. The main objective of this study was to investigate dairy farmers' perceptions and adaptation strategies towards climate change in West Africa. Individual interview and Focus Group Discussions were conducted among 900 dairy farmers. Descriptive statistics and Chi-square test were used to assess dairy farmers' perception on climate change. Multiple Correspondence Analysis and hierarchical clustering on principal component analysis were used to access the adaptation strategies of dairy farmers. The results revealed that dairy farmers perceived a decrease in the rainy season and the annual rainfall but an increase of the dry season and the annual temperature that affect their activities. Dairy farmers that fed the cattle mainly with natural pastures, crops residues and agroindustrial by-products in the climate zones of Benin, Burkina Faso and Niger, used as climate change adaptation strategies, transhumance in wetland, animal manure to improve fodder production and quality; plants to improve milk production, milk conservation and to treat animal diseases. They sold milk or produced local cheese with the remaining unsold milk. They use crops residues, mineral supplements, herd size reduction; water supply with community pastoral wells and dams, purchase water. Dairy farmers that mainly invested in fodder production and conservation in the climate zones of Mali, sold milk produced to dairies and cheese production units; used plants to improve milk production, pasteurization for milk conservation and veterinary service for animal care. This study provided relevant information for West African policymakers in designing appropriate policies and programs to assist dairy farmers to improve milk production under climate variability and change.

\section{Introduction}

In Sub-Saharan Africa, the dairy sector is a major contributor to gross domestic product and plays a crucial role through provision of healthy food and balanced diets (Moffat et al., 2016; Hahlani and Garwi, 2014). Smallholders in most developing countries produce milk, and this contributes to household livelihoods, food security and nutrition. In addition, milk provides relatively quick returns for smallholders and is an important source of income (FAO and ECOWAS, 2018). However, dairy farmers in Sub-Saharan Africa experience more dryness and warmer temperatures; increase in warming will lead to more heat stress and engender a higher prevalence for pests and diseases (Thornton et al., 2009).

The effect of climatic change on dairy production are both direct through effects on the animals themselves, and indirectly through effects on crops production and increased exposure to pests and pathogens (Gauly et al., 2013; Egeru, 2016). The exposure of lactating dairy cows to high ambient temperatures, high relative humidity and solar radiation for extended periods decreases their ability to disperse heat. Warmer and drier conditions increase the likelihood of heat stress in cattle. Heat stress adversely affects reproductive performance in dairy animals (Van den Bossche and Coetzer, 2008). Under heat stress conditions, lactating dairy cows exhibit several physiological responses including a voluntary reduction of feed intake, an increase in maintenance requirements, decrease in milk yield, and milk composition (Cowley et al., 2015). Dairy cows that have experienced high temperature and humidity for a long time will reduce milk production and milk quality. Therefore, the dairy farming is more and more vulnerable to climate change. As result, dairy farming levels continues to decline due to climate variability effects (Moreki and Tsopito, 2013).

Most countries in West Africa are negatively affected by climate change for lack of adequate adaptation capacity (Bryana et al., 2013). Adaptation is the best way to cope with the effects of climate change (Singh et al, 2013). Moreover, climate-related risk perceptions enable dairy farmers to decide for effective adaptation of risk coping strategies (Mercado, 2016; Bakhsh et al, 2018). Understanding dairy farmers' perception on climate change and how they respond to short- and long-term resilience solutions can help them withstand climate disturbances. This is a key factor in planning robust strategies for climate change mitigation and adaptation.

Before adaptation, perception of climate change, as well as its causes and effects, is important to trigger the adaptation process (Niles et al., 2016). Unfortunately, lack of adequate knowledge and information were reported in previous studies as an obstacle to adaptation and therefore calls for good quality, accurate and accessible information (Pandey, 2018). Knowledge is a critical ingredient and the most important input in the process of adaptation (Tripathi and Mishra, 2017). Appropriate coping and adaptation choices are limited, with most farming communities able to make use of only provisional coping or adaptation mechanisms to moderate the effects of climate change (Kosmowski et al., 2016; Wiid and Ziervogel, 2012). The main objective of this study is to investigate West Africa dairy farmers' perception and adaptation strategies towards climate change.

\section{Materials And Methods}

\subsection{Study areas}


The study was carried out in four West African countries Benin, Burkina Faso, Mali and Niger.

Benin is located between the latitudes $6^{\circ} 20^{\prime} \mathrm{N}-12^{\circ} 30^{\prime} \mathrm{N}$ and the longitudes $0^{\circ} 45^{\prime} \mathrm{E}-03^{\circ} 70^{\prime} \mathrm{E}$ (Figure 1). Data were collected in the three climatic zones of the country (Guinean zone, Sudano-Guinean and Sudanian zones). The Guinean zone is characterized by a bimodal rainfall regime (April - June and September - November). The mean annual rainfall is $1200 \mathrm{~mm}$. The temperature ranges from $25 \circ \mathrm{C}$ to 29 ${ }^{\circ} \mathrm{C}$ and the relative humidity from $69 \%$ to $97 \%$. Soils are mainly ferrallitic with hydromorphic soils and black cotton soils in some localities. The Sudano-Guinean zone is characterized by unimodal rainfall varying annually from $900 \mathrm{~mm}$ to $1110 \mathrm{~mm}$. The rainy season is from May to October. The annual temperature of this zone ranges from $25^{\circ} \mathrm{C}$ to $29^{\circ} \mathrm{C}$ and the relative humidity from $31 \%$ to $98 \%$. Soils are mainly ferruginous. The Sudanian zone has one rainy season ranging from May to October and one dry season from November to April. The mean rainfall is $900 \mathrm{~mm}$. The temperature varies from $24^{\circ} \mathrm{C}$ to $31^{\circ} \mathrm{C}$ and the relative humidity from $18 \%$ to $99 \%$.

Burkina Faso extends between the latitudes $9^{\circ} 20^{\prime}-15^{\circ} 05^{\prime} \mathrm{N}$, and the longitudes $5^{\circ} 20^{\prime} \mathrm{W}-2^{\circ} 03^{\prime} \mathrm{E}$. Data were collected in three climates zones (Sudanian, north Sudanian and Sahelian zones). The south Sudanian zone is situated in south of the $11^{\circ} 30^{\prime}$ parallel. The rainy season here lasts six months (May - October) with an average annual rainfall between 900 and $1200 \mathrm{~mm}$. The mean temperature is $26^{\circ} \mathrm{C}$. The north Sudanian zone is situated within the latitudes $11^{\circ} 30^{\prime}$ and $14^{\circ} 00^{\prime} \mathrm{N}$. This zone has an average annual rainfall between $800 \mathrm{~mm}$ and $900 \mathrm{~mm}$ during May to August with about $29^{\circ} \mathrm{C}$. The Sahelian zone is situated in the north of $14^{\circ} 00^{\prime} \mathrm{N}$. This zone has an average annual rainfall between $300 \mathrm{~mm}$ and $600 \mathrm{~mm}$ concentrated into three months (June to August). The mean annual temperature is $34^{\circ} \mathrm{C}$.

Mali is located in western Africa at latitude of 10 to $25^{\circ} \mathrm{N}$, straddling the sub-tropical band called the Sahel. Data were collected in three climatic zones: the Saharo-Sahelian, the Sahelo-Sudanian, and Sudano-Guinean zones. The Saharo-Sahelian zone is extremely dry with an annual rainfall of $100-200 \mathrm{~mm}$ from July to September. The temperature varies from $33^{\circ} \mathrm{C}-36^{\circ} \mathrm{C}$ to $18^{\circ} \mathrm{C}-21^{\circ} \mathrm{C}$. The Sahelo-Sudanian zone (mean annual precipitation $500-700 \mathrm{~mm}$ ) has mean annual temperature of $30^{\circ} \mathrm{C}$. November till February is cool and dry, March to May is hot and dry and June to September is the season of rains. The Sudano-Guinean Zone has mean annual precipitation less than $1200 \mathrm{~mm}$. The Southern Sudanian zone has the mean annual temperatures of $27^{\circ} \mathrm{C}$ and the rainy season from June to October.

Niger is located between $11^{\circ} 65^{\prime}-23^{\circ} 55^{\prime} \mathrm{N}$ and $0^{\circ} 20^{\prime} \mathrm{E}-16^{\circ} 00^{\prime} \mathrm{E}$. Data were collected in three climate zones (Saharan, Sahelo-Saharan and Sahelian zones). The Saharan zone is located in north of latitude $17^{\circ} \mathrm{N}$ with an annual rainfall less than $150 \mathrm{~mm}$ between July and September; the Sahelo-Saharan zone, located between the latitudes $15^{\circ} \mathrm{N}-17^{\circ} \mathrm{N}$, is characterized by an annual rainfall between 150 and $300 \mathrm{~mm}$ from July to September. The Sahelian zone is located at the south of the latitude $15^{\circ} \mathrm{N}$ with a rainfall between 300 and $600 \mathrm{~mm}$ from June to August.

\subsection{Sampling}

The study was conducted in 15 districts in the four countries. These districts were selected due to the high number of cattle, the extent of dairy farming and milk production. In each district, the local administration involved in dairy farming was considered to provide the contact of the farmers. Random sampling was used to select the respondents in each district. 900 respondents were sampled with 60 dairy farmers per district (Table 1).

\subsection{Data collection}

Data were collected using semi-structured interviews. The interview was conducted in the local languages. Moreover, a Focus Group Discussions using semi-structured interview was carried out with different groups (7-8 participants) of pre-selected respondents based on their availability and willingness to participate. The questionnaire was translated in the local language by interviewers especially for those that could neither read nor write French. Further information was obtained through in-depth interview of selected respondents.

Data collected were related to information on dairy farms and characteristics, the perception of dairy farmers on climate change and their adaptation strategies.

\subsection{Data analysis}

Descriptive statistic and Chi-square $\left(\chi^{2}\right)$ analysis were used to assess the independency between the climate zones and countries on the answers close questions related to the perception about the variation in the length of the seasons (rainy and dry season), the variation in the annual rainfall and temperature. The same analysis was used to assess the independency between the climate zones and countries on the answers close questions related to the perception about the impact of the climate change on herd size, livestock fertility, amount of milk produced, fodder availability, microbial proliferation and milk rapid fermentation, the milk quality in terms of color and the fresh milk conservation. 
Dairy farmers' adaptation systems for climatic change were first assessed with Multiple Correspondence Analysis (MCA) performed on individual answers, and then used the MCA factorial axes in a hierarchical clustering on principal component analysis (HCPC). A Chisquare test $\left(\mathrm{X}^{2}\right)$ was used to test the independency between clusters and climatic zones. The analyses were conducted in R software version 3.5.2 (R Core Team, 2019). MCA and HCPC were run using packages ade4 (Dray and Dufour, 2007), FactomineR (Lê et al., 2008), and Factoextra (Kassambara and Mundt, 2016).

\section{Results}

\subsection{Perception of dairy farmers on climate change}

The dairy farmers' perception on climate change varied significantly by country and climate zones. The farmers significantly perceived a change in the length of the rainy and dry season with a decrease of the rainy season and the annual rainfall but increase of the dry season and the annual temperature (Table 2).

With regards to the impact of climate change on dairy farmers' activities, the farmers perceived in general a decrease on herd size with exception of increase in the two climate zones of Burkina-Faso (Sudanian and Sudano-Sahelian zones) and the Guinean zone of Benin (Table 3). The livestock fertility was also perceived to decrease with exception of the two climates zones in Burkina-Faso, the Guinean and the Sudano-Guinean zones in Benin. The amount of milk produced, the availability of fodder, the milk quality mainly in color and the conservation of fresh milk were perceived to decrease in the four countries and the six climate zones while the proliferation of microbial and rapid fermentation of milk were perceived to increase (Table 3).

\subsection{Adaptation strategies adopted in dairy farmers systems towards climate change}

\subsubsection{Typology of dairy farmers systems}

The MCA and HCPC output revealed three groups of dairy farming systems with $60.25 \%$ of the information recorded on all farmers.

The first group represented $63.38 \%$ of the sample $(n=552)$ and their main objective $(73.35 \%$ of the farmers) was the sale of milk produced to milk collectors. They depended mainly on natural pastures and mineral supplements (mineral lickstones) for cattle feeding in addition to collection and use of bush straw. They were married and unschooled. However, $16.80 \%$ of them received literacy classes in their own local language. $67.74 \%$ were under 50 years old and $58 \%$ older than 50 years old. Dairy farmers of this group were also known for their periodic transhumance with the large part of the cattle and kept a small part of cattle on site for their households milk supply. Regarding their herd structure, they had $58.2 \%$ females and $41.8 \%$ males with dominance of young males (male caves and subadults bulls) compared to young females (female calves and heifers). The proportion of cows was higher than reproductive bulls. Their herd size was $147 \pm 15$. This group of dairy farmers was dominant in all countries and climate zones (Figure 2), with a significant proportion in Niger (Sahelian and Sahelo-Saharan zones), Burkina Faso (Sudanian zone) and Mali (Sudanian zone).

The second group represented $19.75 \%$ of the sample $(n=172)$ and their main objective $(65.44 \%)$ was traditional processing of milk into local cheese. They used mainly crops residues, agro-industrial by-products and natural pastures to feed the cattle. Some farmers in this group (22.35\%) sale milk produced to small diaries or milk processing units. $49.33 \%$ of dairy farmers in this group completed primary education. The majority of them $(75.20 \%)$ received also literacy classes in their local language. The animal categories in the herd structure showed significant variations $(p<0.001)$ with high proportion of cows $(67.6 \%)$. Their head size was $115 \pm 13$. This group was in minority in all climatic zones. Their proportion was high in Sahelo-Sudanian zones of Burkina Faso, Sudanian zone of Benin, Guinean zone of Mali and Benin. This group was almost absent in the Sahelian zone of Niger and the Sudano-Sahelian zone of Burkina Faso (Figure 2).

The third group represented $16.88 \%$ of the sample $(n=147)$ and their main objective $(90.32 \%)$ was the sale of the milk produced to dairies and cheese production units. $88.89 \%$ of dairy farmers in this group invested in fodder production. They conserved the fodder using silage technology. They also used crop residues and agro-industrial by-products to feed their livestock. They had little mobility. Some of them $(8.82 \%)$ used the milk to produce local cheese traditionally. Only $8 \%$ of the dairy farmers of this group received literacy classes in the local language. The animal categories in the herd structure showed significant variations $(p<0.001)$ with high proportion of cows $(70.5 \%)$. Their herd size was $47 \pm 20$. Dairy farmers of this group were in low proportion in all climatic zones but abundant in Sahelian, Sudanian and Guinean zones of Mali, Sahelo-Saharan zone of Niger, and Sudano-Guinean zone of Benin (Figure 2).

\subsubsection{Typology of adaptation strategies developed by dairy farmers}


The MCA and HCPC output on the adaptation strategies developed by dairy farmers including strategies for livestock feeding during dry season, water supply, milk production and conservation, revealed three groups of adaptation strategies with $60.25 \%$ of the information recorded on all farmers.

The first group represented $38.92 \%$ of the sample $(n=339)$. In this group, the farmers fed the cattle during the dry season with transhumance in wetlands, spread animal manure in dried natural pastures to improve fodder production and their nutritional value. They harvested rainwater and used natural water supplies (streams, rivers, marshes, swamp, wetlands, and shallow-water) as adaptation strategies for water supply. Galactogenic plants including the leaves of Sorghum bicolor, Spondias mombin, Annona senegalensis, Daniellia oliveri, Vitellaria paradoxa and Euphorbia hirta (Figure 4A) were used to increase the milk produced by the cattle. Essential oils and nectar extracted from Calotropis procera, Carica papaya and Balanites aegyptiaca (Figure 4B) were used to conserve the milk in order to avoid the rapid fermentation or even spoilage of the milk as well as the processing of the milk into local cheese. Plants used to control milk fermentation included Calotropis procera, Ocimum gratissimum, Cymbopogon citratus, Pimenta racemosa and Zingiber officinale (Figure 4B). Medicinal plants were also used to treat animal diseases. This adaptation system was mostly used by dairy farmers in Guinean, Sudanian and Sudano-Guinean zones of Benin (Figure 3).

The second group represented $24.23 \%$ of the sample $(n=211)$. In this group, farmers fed their cattle during the dry season with fodder production and silage technology. Treatment of bush straw with urea was also used to improve their nutritional value. To cope with water supply issues in the dry season, sink of boreholes and wells in dry places were used.

Galactogenic plants including Euphorbia hirta, Spondias mombin, Secamone afzelii, Ficus sycomorus, Mucuna pruriens and Annona senegalensis (Figure 4A) were used to increase the amount of milk produced by the cattle. Pasteurization was used to conserve the milk against its rapid fermentation, and veterinary service was used for animal care. This adaptation system was mainly used by dairy farmers in Guinean, Sudanian and Sahelian zones of Mali, as well as dairy farmers in Sudanian zone of Burkina Faso (Figure 3).

The third group represented $36.85 \%$ of the sample $(n=321)$. In this group, the farmers fed the cattle during the dry season with crops residues and mineral supplements (lickstones). They reduced the herd size by selling some young bulls and cull cows to overcome feeding difficulties. In addition, herd diversification with sheep and goats was also used as a strategy to address feeding issues. To improve cattle ration, supplements based on oil-cakes or multi-nutritional blocks was used. For water supply, they used community pastoral wells and dams in addition to water purchase at the village public water pump. Galactogenic plants including Spondias mombin, Balanites aegyptiaca, Ficus gnaphalocarpa, Pergularia tomentosa, Annona senegalensis, Daniellia oliveri and Boswellia dalzielii (Figure 4A) were used to increase the milk produced by the cattle. The milk was immediately sold to dairies and milk processing units or stored in appropriate calabashes/wooden gourds made with Pterocarpus erinaceus, Acacia nilotica and Balanites aegyptiaca, to overcome milk fermentation (Figure 4B). Moreover, essential oil and juice extracted from the leaves of Calotropis procera, Annona senegalensis and Carica papaya were also used to control milk fermentation. Medicinal plants were used to treat animals. This adaptation system was mainly adopted by dairy farmers in Sahelian, Sahelo-Saharan zones of Niger, as well as dairy farmers in Sahelo-Sudanian zones of Burkina Faso (Figure 3).

\subsubsection{Relationships between dairy farming systems and adaptation strategies}

The relationship between dairy farming systems and adaptations systems (Figure 5) revealed that dairy farmers transhumant that used natural pastures and mineral lickstones to feed the cattle and sold the milk produced to milk collectors (group 1) in the climate zones of Benin, Burkina Faso and Niger, used as adaptation strategies towards climate change, transhumance in wetland, improve fodder production and quality with animal manure; plants to improve milk production and conservation and to treat animal disease, (adaptation system 1) in addition to the use of crops residues, mineral supplements, herd size reduction; water supply with community pastoral wells and dams as well as to purchase water; plants to improve milk production and conservation in addition to immediate milk sale (adaptation system 3).

The dairy farmers that used mainly crops residues, agro-industrial by-products to feed the cattle; sold the milk produced and collected and also used to transform the milk in local cheese (group 2) in the climate zones of Benin used the adaptation system 1 only towards climate change.

The dairy farmers that mainly invested in fodder production and conserved the fodder using silage technology sold the milk produced to dairies and milk processing units and also used to transform the milk in local cheese (group 3) in the climate zones of Mali; used as adaptation strategies towards climate change, fodder production, conservation or treated with urea to feed their cattle in the dry season. 
They also used plants to improve milk production, pasteurization for milk conservation and veterinary service for animal care (adaptation system 2) (Figure 5).

\section{Discussion}

\subsection{Perception of dairy farmers on climate change}

The dairy farmers in the four countries and the six climate zones perceived a decrease of the rainy season and the annual rainfall but increase of the dry season and the annual temperature. Annual rainfall decrease was less perceived by dairy farmers in the Guinea zone of Benin and the Sudano-Guinean zone of Mali. This could be explained by the declining of rainfall as one ascends from the Guinean zone to the Saharan zone. Results from several studies revealed an increase in temperature and a decrease in rainfall across many African rural regions (IPCC, 2014; Debela et al., 2015). In most West African countries, climate change effects are characterized by recurrent droughts, altered rainfall regimes with deficits in the order of $20-30 \%$ and decreases in stream-water flows (Sarr et al., 2012). Similar perceptions on climate change were reported in previous studies (Debela et al., 2015; Kosmowski et al., 2016). In contrast, other studies indicated an increase in rainfall amounts that lead sometimes to flooding (Mertz et al., 2009, 2012; Sofoluwe et al., 2011).

The farmers perceived that increase temperature is related to the decrease in rainfall and induce a decrease on herd size, livestock fertility, milk production, fodder availability and milk conservation but increase of the proliferation of microbial and rapid fermentation of milk. During the dry season, temperature causes a large part of rainfall evaporation. Livestock production would be severely affected in a region where increase temperature is related to decrease in rainfall (Sirohi and Michaelowa, 2007). The frequent droughts lead to the drying up of the natural pastures and induce severe livestock feeding issues. The increase in temperature has significant impact on water availability and pasture resources including fodder quantity and quality, animal and rangeland biodiversity, management practices and production systems (Herrero et al., 2009, 2010).

The decrease in milk production in terms of quantity and quality may be a consequence of the persistent drought conditions that lead to a reduction of fodder during the lactation period of dairy cows. Increase in temperature and recurrent drought periods adversely affect milk production and cattle growth (Hidosa and Guyo, 2017; Kimaro et al., 2018). Moreover, increase in temperature facilitates the appearance and proliferation of certain parasites and diseases that may reduce the milk production as air temperature has significant direct effect on animals' health, milk production and reproduction rate (Herbut et al., 2018; Mustafa et al., 2019). Exception of increase on herd size and livestock fertility was perceived in the two climate zones of Burkina-Faso (Sudanian and Sudano-Sahelian zones) and the Guinean zone of Benin. This might be due to the high presence in these areas of pastoralists' transhumant from other dry regions of West Africa. The availability of fodder, in quantity and quality, being a crucial factor for pastoralism in the Sahel, many herders transhumant move to wetlands (Deygout and Treboux, 2012). The pastoral areas of Benin host every year national and trans-border transhumant herders with a very large number of herds. The factors determining the choice of Sudanian regions of Benin as favorite destinations for West African transhumant herders remain the availability of fodder and water resources (Kagoné et al., 2006). In Benin, the Upper Alibori classified forest is today one of the favorite destinations for national and foreign transhumant herders and the agricultural and pastoral pressures on the resources of this forest are increasing (Assani et al., 2017). Several studies also pointed out that the Regional Park W and other protected parks in northern Benin are under strong pressure from transhumant herds (CORAF/WECARD, 2015; Gado et al., 2020). Entry into the pastoral areas of the Guinean and Sudanese regions of Benin began with the 1973 and 1984 droughts (Toutain et al., 2004 and Boutrais, 2008) and the eradication of tsetse flies which forced transhumant herders from the Sahel (Niger and Mali) to move into the protected areas of northern Benin. All this has contributed both to the increase of herd size and livestock fertility.

\subsection{Adaptation systems adopted by dairy farmers towards climate change}

Three types of dairy farmers systems were observed with different objectives. Only the first system used to sell the total milk produced while the two others systems used to transform the milk into local cheese in addition to milk sale. The difference observed in the objectives may be due to the livestock feeding mode. In the first system, the farmers are transhumant and use natural pastures and mineral lickstones to feed the cattle, while in the others systems, they use mainly crops residues, agro-industrial by-products (group 2) and invested in fodder production and conserved the fodder using silage technology (group 3) to feed the cattle. The dairy cow feeding mode or practices has a great impact on milk composition and cheese production. For example, goats fed a high concentrate level with pasture grazing produced milk with significantly higher contents of fat, protein and total solids and thus had a higher cheese yield than goats grazed pasture alone without concentrate supplementation or under a confined feeding system with concentrate but without pasture grazing (Soryal et al., 2004). Cheeses made from the milk of cows fed sunflower cake have a high fat content (Zhang et al., 2006). This is because the composition of milk fatty acids is often affected by rumen biohydrogenation and conversion of the enzyme D9-desaturase (C18:0 to C18:1, Bauman and Griinari, 2003), but the large changes of milk fat composition can be achieved by changing the nature of

Page 6/17 
forages in the diets. For example, Chilliard et al. (2007) reviewed data relating to the fatty acids composition of milk from animals fed hay, fresh grass and maize silage and reported changes to the content. Diets formulated with higher quality forages increased the milk fat content and milk yield of dairy cows, whereas low quality forages containing fewer nutrients would result in the reduction of milk yield and a decrease in milk fat synthesis (Zhu et al., 2013). The composition and physical characteristics of milk influence its process ability for products such as cheese. The two most important milk solids in cheese making are protein (particularly casein) and fat (Amenu and Deeth, 2007). These aforementioned milk components vary according to the diet of the dairy cows and justify the choice of the dairy farms objectives (milk or cheese) based on the feeding mode.

Three types of adaptation systems were observed based on the solutions used to cope with issues related to livestock feeding, access to water, and milk quantity and its conservation. The livestock feeding strategy based only on natural vegetation or use of crops residues and mineral supplements is more vulnerable to climate change compared to the feeding strategy based on fodder and silage production. High temperatures tend to increase lignification in plant tissues and hence decrease the digestibility of forage and concurrently induced a shift from C3 grass species to C4 grasses which has direct implications for forage supply (Tubiello et al. 2007). Similarly, when the climates become hotter and drier; pasture composition is likely to shift to species that may be less suitable for grazing (Escarcha et al., 2018). Lower the climate change affects the productivity and grazing capacity of rangelands, higher the nutritional stresses in livestock are likely to suffer, further exacerbating the existing vulnerability of pastoral systems (Hidosa and Guyo, 2017) As grasses and legumes from natural grazing areas decline in quality and quantity during the dry season, forages should be conserved in form of hay and silage to ensure adequate forage supply during scarcity in the dry season (Lamidi and Ologbose, 2014). The performance of ruminant animals which is dependent on the native pasture is seriously impaired with the long droughts; the quality is associated with the fibrous and lignified nature of the pasture which limits intake, digestibility and utilization (Olafadehan et al., 2009; Lamidi et al., 2013). Conserving forage as silage is an option to alleviate feed constraints and maintain animal productivity during dry periods (Reiber et al., 2010). Moreover, in areas with a long dry season, tropical pastures rarely provide sufficient year-round feed of reasonable quality to match the nutritional demands of livestock and support satisfactory livestock production and reproduction (Reiber et al., 2010). The use of by-products for supplementary livestock feeding is justified when the forage supply is inadequate for animal needs either in terms of quantity or quality (Borogo et al., 2006; Aina, 2012). Increased usage of silage-making technology using improved forages and feeds to overcome the dry season feed deficits in the dry tropics seemed possible by application of appropriate technology transfer strategies (Reiber et al., 2010). Farmer motivation and participatory technology experimentation, evaluation and development were particularly important in areas where silage was less known. Once there are positive examples, adapted and efficient silage technologies should be scaled-out through demonstrations and exchange of experiences ('promotion of adoption' and/or farmer-to-farmer approach). The water supply with only natural water supplies is also vulnerable. In arid and semiarid regions, precipitation is generally lower than potential evaporation and non-uniform in distribution, resulting in frequent drought periods (Oweis and Hachum, 2009). As the water shortage in dry areas is a recurring crisis, capturing rainwater and making effective use of it is crucial. Water harvesting can play an important role in fulfilling the objectives of such agricultural or livestock projects. Farmers need information on how to capture and use every available drop of water efficiently (Oweis and Hachum, 2009).

The three systems use galactogenic plants to increase milk production. An effective nutritional regime and use of herbal galactogogues act synergistically to enhance milk yield which would prompt a good augmentation in productivity of dairy herd. Herbal galactogogues act through interactions with dopamine receptors by exerting an influence through adreno-hypothalamo-hypophysealgonadal axis resulting in enhanced prolactin concentration and thereby augmenting milk production (Gbadamosi and Okolosi, 2013; Mohanty et al., 2014). Thus these galactogenic plants (booster for lactation) constitute an alternative to improve milk production and cope with climate change effects on milk yield. In order to restore the animal productivity and to optimize the milk production in individual animals for better profits, various herbal preparations, hormones, mineral supplements and feed additives have been tried (Ramesh et al.,2000; Bhat et al, 2009). Galactin a non-hormonal herbal preparation significantly enhanced the milk production in dairy cows and ultimately improved the dairy economics (Ramesh et al., 2000; Kumari and Akbar, 2006). Herbal preparations have also been shown to relieve the heat stress in dairy cows and ultimately improve their productivity (Zhang et al., 2006). Indigenous herbal preparations effectively restored the altered milk constituents and increased the milk production in cows with sub-clinical mastitis (Kolte et al., 2008). Thus is important to setup a domestication program on these plants in order to sustain their conservation and use for the dairy production.

Except in adaption system two where the milk is pasteurized for the conservation, the others systems use plant for milk conservation. It is important to setup a domestication of the plant use to conserve milk in order to sustain they use for dairy production. The use of plant extracts and essential oils in consumer goods is expected to increase in the future because volatile oils can be considered as a natural alternative to synthetic food preservatives and could be used to enhance food safety and shelf life (Samaddar et al., 2015). However our study revealed that the use of plant species for milk conservation is more vulnerable than pasteurization. This can be explained by the fact that it's difficult to define and measure the specific quantity of plant material to be added, to ensure an expected antimicrobial effect in

Page 7/17 
food, in addition to the need of analytical methods for a more accurate determination of these compounds (Calo et al., 2015). Stability of natural compounds must also be taken into account when they are added to food. Such compounds are usually sensitive to oxygen, light, temperature, and pH (Dima, 2015) and may be lost during milk preservation, cheese processing and preservation. Libran et al. (2013) observed a decrease in the content of compounds from Ocimum basilicum (basil) and Tanacetum vulgare (tansy) added during the production of cheese. Similarly, $37.49 \%$ of the total volatiles of rosemary essential oils (Rosmarinus officinalis) added to sheep milk were lost during cheese production, as a certain portion was lost in the whey (Moro et al., 2015). Thus, the concentration of plant extracts and essential oils to be incorporated into cheese must supply the possible losses during production and interaction with food, in order to provide adequate microbiological inhibition (Hassanien et al., 2014; Moro et al., 2015). Pasteurized milk has suitable nutrition value for daily use, but its shelf life is only two weeks under refrigeration at $4^{\circ} \mathrm{C}$ (Nasr and Elshaghabee, 2019). However, the synergistic effect of Nisplin® combination in emulsion with natural essential oils extracted from plant such as cinnamon (Cinnamomum cassia), clove (Syzygium aromaticum), ginger (Zingiber officinale) and jojoba (Simmondsia chinensis) as safe food additives extend the shelf life of pasteurized milk under poor refrigeration conditions at $10^{\circ} \mathrm{C}$ and help to achieve commercial and social benefits for the community (Nasr and Elshaghabee, 2019). The combination of pasteurization and the use of essential oils or plants latex is the best strategy to conserve milk in the rural areas of the climate regions studied across West Africa.

The first and the third adaptation systems use medicinal plant for livestock care while the second adaptation system relies on veterinary service. Conventional veterinary and ethnoveterinary medicine, even by taking into account their heterogenosity, must act jointly to realize their shared goal which is the preservation of health and welfare of animals (Davidović et al., 2012). Medicinal herbs, along with some other herbs, are used both separately and as an additional therapy to conventional drugs which can, in this case, thanks to the action of active plant ingredients, be used in lower, safer doses. It is possible to direct curative effect of plants in a certain direction, to strengthen or alleviate their action by combining certain features of some plants and their preparations (Gerzilov et al., 2011). In many rural communities of developing countries, dairy farmers use of plants as veterinary medicines are very common. Most of them depend on traditional or folk medicines or household remedies for the treatment of diseases from which they themselves or their domestic animals suffer from (Das et al., 2011).

The first adaptation system was mostly used by dairy farmers in Guinean, Sudanian and Sudano-Guinean zones of Benin. The second adaptation system was mainly used by dairy farmers in Guinean, Sudanian and Sahelian zones of Mali, as well as dairy farmers in Sudanian zone of Burkina Faso. The third adaptation system was mainly adopted by dairy farmers in Sahelian, Sahelo-Saharan zones of Niger, as well as dairy farmers in Sahelo-Sudanian zones of Burkina Faso. It's clear that adaptation strategies varied depending on climate zones and countries as well as the dairy farmer's production targets, livestock structure, demographic characteristics and available resources. This should be taken into account in the elaboration of the sustainable adaptation strategy towards climate change for dairy farmers.

\section{Conclusion}

Dairy farmers in West Africa currently perceive a decrease in rainy season and rainfall but increase in dry season and temperature. This has induced a decrease on herd size, livestock fertility, milk production, fodder availability and milk conservation but increase of the proliferation of microbial and rapid fermentation of milk.

Dairy farmers that feed the cattle mainly with natural pastures and agricultural products in the climate zones of Benin, Burkina Faso and Niger, used as climate change adaptation strategies, transhumance in wetlands. They used also animal manure to improve fodder production and quality while some plants to improve milk production, conservation and to treat animal disease. They used to sell the milk or produce local cheese with a part. They use crops residues, mineral supplements, herd size reduction; water supply with community pastoral wells and dams, purchase water.

Dairy farmers that mainly invest in fodder production and conservation in the climate zones of Mali sell the milk produced to dairies and cheese production units; use plants to improve milk production, pasteurization for milk conservation and veterinary service for animal care.

\section{Declarations}

\section{Acknowledgements}

We thank the dairy farmers of Benin, Burkina Faso, Mali and Niger for sharing their perception and adaptation strategies towards Climate Change in West Africa. 
MM coordinated the data collection, EAP and MMa coordinated the data analyses, MNM and BS writing of this paper, to which all authors contributed.

\section{Funding}

This work was supported through the Climate Research for Development (CR4D) Postdoctoral Fellowship [CR4D-19-12\#] implemented by the African Academy of Sciences (AAS) in partnership with the United Kingdom's Department for International Development (DfID) Weather and Climate Information Services for Africa (WISER) programme and the African Climate Policy Center (ACPC) of the United Nations Economic Commission for Africa (UNECA). Statements made and views expressed in this work are solely the responsibility of the author(s).

\section{Ethical Approval}

The dairy farmers gave voluntarily consent that can be withdrawn at any time. Prior sensitization was provided to dairy farmers about the research activities and benefices to them before recruitment of participants in order to assure voluntariness. We provided to the participants, full disclosure of all information necessary for making an informed decision to participate in the research and gave them adequate time and opportunity to assimilate the information provided, pose any questions they may have, and discuss and consider whether they will participate. The activities began only after the participants provided their consent. We used either written signed consent or oral consent depending on the formal education or literacy of the participants. Consent was maintained throughout the research. Interviews conducted were anonymous and no unnecessary personal data on the interviewed person were collected.

\section{Availability of data and materials}

Data are available upon request from co-authors.

\section{References}

1. Amenu, B., \& Deeth, H. C. (2007). The impact of milk composition on cheddar cheese manufacture. Australian Journal of Dairy Technology, 62(3), 171.

2. Assani, S. A., Alkoiret, T. I., Baco, M. N., \& Houinato, M. (2017). Transhumance map and pastoral calendar of cattle herds exploiting the forage resources of the Classified Forest of Upper Alibori Northern Benin. Int Res J Nat App/ Sci, 4(4), 50-70.

3. Bakhsh, K., Rauf, S., \& Zulfiqar, F. (2018). Adaptation strategies for minimizing heat wave induced morbidity and its determinants. Sustainable cities and society, 41, 95-103.

4. Bauman, D. E., \& Griinari, J. M. (2003). Nutritional regulation of milk fat synthesis. Annual review of nutrition, 23(1), $203-227$.

5. Bhatt, N., Singh, M., \& Ali, A. (2009). Effect of feeding herbal preparations on milk yield and rumen parameters in lactating crossbred cows. International Journal of Agriculture and Biology, 11(6), 721-726.

6. Bogoro, S., Kalia, D., \& Fomukong, B. (2006). Chemical composition and in situ rumen degradability of blood meal and urea-treated crop residues. Nigerian Journal of Experimental and Applied Biology, 7(1), 27-35.

7. Boutrais, J., Aubertin, C., \& Rodary, E. (2008). Pastoralisme et aires protégées d'Afrique de l'Ouest en regard de l'Afrique de l'Est. Aires protégées, espaces durables, 215-246.

8. Bryan, E., Ringler, C., Okoba, B., Roncoli, C., Silvestri, S., \& Herrero, M. (2013). Adapting agriculture to climate change in Kenya: Household strategies and determinants. Journal of environmental management, 114, 26-35.

9. Calo, J. R., Crandall, P. G., O'Bryan, C. A., \& Ricke, S. C. (2015). Essential oils as antimicrobials in food systems-A review. Food control, 54, 111-119.

10. Chilliard, Y., Glasser, F., Ferlay, A., Bernard, L., Rouel, J., \& Doreau, M. (2007). Diet, rumen biohydrogenation and nutritional quality of cow and goat milk fat. European Journal of Lipid Science and Technology, 109(8), 828-855.

11. CORAF/WECARD (2015).Transhumance transfrontalière et conflits liés à l'utilisation des ressources naturelles en Afrique de l'Ouest.

12. Cowley, F. C., Barber, D. G., Houlihan, A. V., \& Poppi, D. P. (2015). Immediate and residual effects of heat stress and restricted intake on milk protein and casein composition and energy metabolism. Journal of dairy science, 98(4), 2356-2368.

13. Das, N. N., \& Mohanty, B. P. (2006). Root zone soil moisture assessment using remote sensing and vadose zone modeling. Vadose Zone Journal, 5(1), 296-307. 
14. Davidović, V., Todorović, J. M., Stojanović, B., \& Relić, R. (2012). Plant usage in protecting the farm animal health. Biotechnology in Animal Husbandry, 28(1), 87-98.

15. Debela, N., Mohammed, C., Bridle, K., Corkrey, R., \& McNeil, D. (2015). Perception of climate change and its impact by smallholders in pastoral/agropastoral systems of Borana, South Ethiopia. SpringerPlus, 4(1), 236.

16. Deygout, P., Treboux, M., \& Bonnet, B. (2012). Systèmes de production durables en zones sèches: quels enjeux pour la coopération au développement. Rapport complet.

17. Dima, C., \& Dima, S. (2015). Essential oils in foods: extraction, stabilization, and toxicity. Current Opinion in Food Science, 5, $29-35$.

18. Dray, S., \& Dufour, A. B. (2007). The ade4 package: implementing the duality diagram for ecologists. Journal of statistical software, 22(4), 1-20.

19. Egeru, A. (2016). Climate risk management information, sources and responses in a pastoral region in East Africa. Climate Risk Management, 11, 1-14.

20. Escarcha, J. F., Lassa, J. A., \& Zander, K. K. (2018). Livestock under climate change: a systematic review of impacts and adaptation. Climate, 6(3), 54.

21. FAO and ECOWAS. (2018) Review of the Livestock/Meat and Milk Value Chains and Policy Influencing Them in West Africa. Retrieved from: http://www.fao.org/3/a-i5275e.pdf

22. Gado, B. O. K., Imorou, I. T., Arouna, O., \& Oumorou, M. (2020). Caractérisation des parcours de transhumance à la périphérie de la réserve de biosphère transfrontalière du W au Bénin. International Journal of Biological and Chemical Sciences, 14(2), 333-352.

23. Gauly, M., Bollwein, H., Breves, G., Brugemann, K., Danicke, S., Das, G., \& Loholter, M. (2013). Future consequences and challenges for dairy cow production systems arising from climate change in Central Europe-a review. - a Review Animal, 7, 843-859.

24. Gbadamosi, I. T., \& Okolosi, O. (2013). Botanical galactogogues: nutritional values and therapeutic potentials. Journal of Applied Biosciences, 61, 4460-4469.

25. Gerzilov, V., Bozakova, N., Bochukov, A., Penchev, G., Lyutskanov, M., Popova-Ralcheva, S., \& Sredkova, V. (2011). Influence of the prebiotic Salgard and a herb mixture on pekin ducklings in organic poultry production, I: Growth performance and blood biochemical parameters. Biotechnology in Animal Husbandry, 27(1), 33-43.

26. Hahlani, C. D., \& Garwi, J. (2014). Operational challenges to smallholder dairy farming: The case of mayfield dairy settlement scheme in Chipinge District of Zimbabwe. IOSR Journal of Humanities and Social Science, 19(1), 87-94.

27. Hassanien, M. F. R., Mahgoub, S. A., \& El-Zahar, K. M. (2014). Soft cheese supplemented with black cumin oil: Impact on food borne pathogens and quality during storage. Saudi Journal of Biological Sciences, 21(3), 280-288.

28. Herrero, M., Thornton, P. K., Gerber, P., \& Reid, R. S. (2009). Livestock, livelihoods and the environment: understanding the trade-offs. Current Opinion in Environmental Sustainability, 1(2), 111-120.

29. Herrero, M., Thornton, P. K., Notenbaert, A. M., Wood, S., Msangi, S., Freeman, H. A., \& Lynam, J. (2010). Smart investments in sustainable food production: revisiting mixed crop-livestock systems. Science, 327(5967), 822-825.

30. Herbut, P., Angrecka, S., \& Walczak, J. (2018). Environmental parameters to assessing of heat stress in dairy cattle-a review. International journal of biometeorology, 62(12), 2089-2097.

31. Hidosa, D., \& Guyo, M. (2017). Climate change effects on livestock feed resources: a review. J. Fish. Livest Prod, 5, 259.

32. Intergovernmental Panel on Climate Change (IPCC) (2014). Climate Change 2014: impacts, adaptation and vulnerability. Contribution of Working Group II to the Fifth Assessment Report of the Intergovernmental Panel on Climate Change. Cambridge University Press, Cambridge, UK \& New York, USA. Available at: www.ipcc.ch/report/ar5/wg2.

33. Kagoné, H., Toutain, B., Dulieu, D., Houinato, M., Boureïma, A., \& Nocker, U. (2006). Pastoralism and protected area in West Africa: from conflict to concerted management of transboundary transhumance in the region of the "W" national park (Benin, Burkina Faso, Niger). Bulletin of Animal Health and Production in Africa, 54(1), 43-52.

34. Kassambara, A., \& Mundt, F. (2016). Factoextra: Extract and Visualize the Results of Multivariate Data Analyses. r Package Version 1.0. 3, 2016.

35. Kimaro, E. G., Mor, S. M., \& Toribio, J. A. L. (2018). Climate change perception and impacts on cattle production in pastoral communities of northern Tanzania. Pastoralism, 8(1), 19.

36. Kolte, A. Y., Waghmare, S. P., Mode, S. G., \& Handa, A. (2008). Efficacy of indigenous herbal preparation on altered milk pH, somatic cell count and electrolyte profile in subclinical mastitis in cows. Veterinary World, 1(8), 239.

37. Kosmowski, F., Leblois, A., \& Sultan, B. (2016). Perceptions of recent rainfall changes in Niger: a comparison between climate-sensitive and non-climate sensitive households. Climatic change, 135(2), 227-241.

Page 10/17 
38. Kumari, R., \& Akbar, M. A. (2006). Clinical efficacy of some herbal drugs during indigestion in buffaloes. Buffalo Bull, 25, 3-6.

39. Lamidi, A. A., Aina, A. B. J., \& Alikwe, P. C. N. (2013). Digestibility and Nitrogen Balance of Sole Malted Sorghum Sprout, Maize Stover and Rice Straw in West African Dwarf Goat. African Journal of Livestock Extension, 11, 6-10.

40. Lamidi, A. A., \& Ologbose, F. I. (2014). Dry season feeds and feeding: a threat to sustainable ruminant animal production in Nigeria. Journal of Agriculture and Social Research (JASR), 14(1), 17-30.

41. Lê, S., Josse, J., \& Husson, F. (2008). FactoMineR: an R package for multivariate analysis. Journal of statistical software, $25(1)$, 1-18.

42. Librán, C. M., Moro, A., Zalacain, A., Molina, A., Carmona, M., \& Berruga, M. I. (2013). Potential application of aromatic plant extracts to prevent cheese blowing. World journal of microbiology and biotechnology, 29(7), 1179-1188.

43. Mercado, R. M. (2016). People's risk perceptions and responses to climate change and natural disasters in BASECO compound, Manila, Philippines. Procedia Environmental Sciences, 34, 490-505.

44. Mertz, O., Mbow, C., Reenberg, A., \& Diouf, A. (2009). Farmers' perceptions of climate change and agricultural adaptation strategies in rural Sahel. Environmental management, 43(5), 804-816.

45. Mertz, O., D’haen, S., Maiga, A., Moussa, I. B., Barbier, B., Diouf, A., \& Dabi, D. (2012). Climate variability and environmental stress in the Sudan-Sahel zone of West Africa. Ambio, 41(4), 380-392.

46. Moffat, F., Khanal, S., Bennett, A., Thapa, T. B., \& Malakaran George, S. (2016). Technical and investment guidelines for milk cooling centres.

47. Moreki, J. C., \& Tsopito, C. M. (2013). Effect of climate change on dairy production in Botswana and its suitable mitigation strategies. Online Journal of Animal and Feed Research, 3(6), 216-221.

48. Moro, A., Librán, C. M., Berruga, M. I., Carmona, M., \& Zalacain, A. (2015). Dairy matrix effect on the transference of rosemary (Rosmarinus officinalis) essential oil compounds during cheese making. Journal of the Science of Food and Agriculture, 95(7), 15071513.

49. Mustafa, G., Latif, I. A., Bashir, M. K., Shamsudin, M. N., \& Daud, W. M. N. W. (2019). Determinants of farmers' awareness of climate change. Applied Environmental Education \& Communication, 18(3), 219-233.

50. Nasr, N., \& Elshaghabee, F. (2019). Enhancement of Shelf Life of Pasteurized Milk Using NisplinŪ Essential Oils Emulsion. Int. J. Curr. Microbiol. App. Sci, 8(9), 257-266.

51. Niles, M. T., Brown, M., \& Dynes, R. (2016). Farmer's intended and actual adoption of climate change mitigation and adaptation strategies. Climatic Change, 135(2), 277-295.

52. Olafadehan, O. A., \& Adewumi, M. K. (2009). Productive and reproductive performance of strategically supplemented free grazing prepartum Bunaji cows in the agropastoral farming system. Tropical animal health and production, 41(7), $1275-1281$.

53. Oweis, T., \& Hachum, A. (2009). Water harvesting for improved rainfed agriculture in the dry environments. Rainfed Agriculture: Unlocking the Potential; Wani, SP, Ed.; CAB International: London, UK, 164-182.

54. Pandey, R., Kumar, P., Archie, K. M., Gupta, A. K., Joshi, P. K., Valente, D., \& Petrosillo, I. (2018). Climate change adaptation in the western-Himalayas: Household level perspectives on impacts and barriers. Ecological Indicators, 84, $27-37$.

55. Ramesh, P.T., S.K. Mitra, T. Suryanarayan and A. Sachan, 2000. Evaluation of Galactacin a herbal galactagogue preparation in dairy cows. The Veterinarians, 24: 1-3

56. Reiber, C., Schultze-Kraft, R., Peters, M. and Hoffmann, V. (2010) Potential and constraints of little bag silage forsmallholders - results and experiences from Honduras. Experimental Agriculture, 45(2), 209-220.

57. Sarr, B., Kafando, L., \& Atta, S. (2011). Identification des risques climatiques de la culture du maïs au Burkina Faso. International Journal of Biological and Chemical Sciences, 5(4), 1659-1675.

58. Samaddar M, Ram C, Sen M, 2015. Assessment of storage stability of essential oil enriched flavoured milk. Indian J. Dairy Sci 68(4): 357- 363.

59. Singh, S. K., Meena, H. R., Kolekar, D. V., \& Singh, Y. P. (2012). Climate change impacts on livestock and adaptation strategies to sustain livestock production. J Vet Adv, 2(7), 407-412.

60. Sirohi, S., \& Michaelowa, A. (2007). Sufferer and cause: Indian livestock and climate change. Climatic change, 85(3-4), $285-298$.

61. Sofoluwe, N. A., Tijani, A. A., \& Baruwa, O. I. (2011). Farmers perception and adaptation to climate change in Osun State, Nigeria. African Journal of Agricultural Research, 6(20), 4789-4794.

62. Soryal, K. A., Zeng, S. S., Min, B. R., Hart, S. P., \& Beyene, F. A. (2004). Effect of feeding systems on composition of goat milk and yield of Domiati cheese. Small Ruminant Research, 54(1-2), 121-129. 
63. Thornton, P. K., van de Steeg, J., Notenbaert, A., \& Herrero, M. (2009). The impacts of climate change on livestock and livestock systems in developing countries: A review of what we know and what we need to know. Agricultural systems, 101(3), 113-127.

64. Toutain, P. L., \& Lees, P. (2004). Integration and modelling of pharmacokinetic and pharmacodynamic data to optimize dosage regimens in veterinary medicine. Journal of veterinary pharmacology and therapeutics, 27(6), 467-477.

65. Tubiello, F. N., Amthor, J. S., Boote, K. J., Donatelli, M., Easterling, W., Fischer G., Rosenzweig, C. (2007). Crop response to elevated CO2 and world food supply: a comment on "Food for Thought..." by Long et al., Science 312: 1918-1921, 2006. European journal of agronomy, 26(3), 215-223.

66. Tripathi, A., \& Mishra, A. K. (2017). Knowledge and passive adaptation to climate change: An example from Indian farmers. Climate Risk Management, 16, 195-207.

67. den Bossche Van, P., \& Coetzer, J. A. (2008). Climate change and animal health in Africa. Revue scientifique et technique (International Office of Epizootics), 27(2), 551-562.

68. Wiid, N., \& Ziervogel, G. (2012). Adapting to climate change in South Africa: commercial farmers' perception of and response to changing climate. South African Geographical Journal, 94(2), 152-173.

69. Zhang, R. H., Mustafa, A. F., \& Zhao, X. (2006). Effects of feeding oilseeds rich in linoleic and linolenic fatty acids to lactating ewes on cheese yield and on fatty acid composition of milk and cheese. Animal Feed Science and Technology, 127(3-4), $220-233$.

70. Zhu, W., Fu, Y., Wang, B., Wang, C., Ye, J. A., Wu, Y. M., \& Liu, J. X. (2013). Effects of dietary forage sources on rumen microbial protein synthesis and milk performance in early lactating dairy cows. Journal of Dairy Science, 96(3), 1727-1734.

\section{Tables}

Table 1: Distribution of respondents in the study area

\begin{tabular}{|llll|}
\hline Country & Climate zones & Number of district & Sample size \\
\hline Benin & Guinean & 1 & 60 \\
\cline { 2 - 4 } & Sudano-Guinean & 3 & 180 \\
\cline { 2 - 4 } Burkina Faso & Sudanian & 2 & 120 \\
& Sudanian & 1 & 60 \\
\cline { 2 - 4 } Mali & Sudano-Sahelian & 2 & 120 \\
& Guinean & 1 & 60 \\
\cline { 2 - 4 } & Sudanian & 1 & 60 \\
\cline { 2 - 4 } Niger & Sahelian & 1 & 60 \\
& Sahelian & 2 & 60 \\
\cline { 2 - 4 } & Sahelo-Saharan & 1 & 120 \\
\cline { 2 - 4 } & & & 6
\end{tabular}

Table 2. Dairy farmers' perception on season, rainfall and temperature variation 


\begin{tabular}{|c|c|c|c|c|c|c|c|c|c|c|c|c|}
\hline \multirow[t]{2}{*}{ Statements } & \multicolumn{2}{|l|}{$\mathrm{GZ}$} & \multirow{2}{*}{$\frac{\text { SGZ }}{\text { Benin }}$} & \multicolumn{3}{|l|}{ SZ } & \multirow{2}{*}{$\begin{array}{l}\text { SSZ } \\
\text { Burkina }\end{array}$} & \multicolumn{2}{|l|}{ ShZ } & \multirow{2}{*}{$\begin{array}{l}\text { ShSha } \\
\text { Niger }\end{array}$} & \multirow[t]{2}{*}{ Global } & \multirow[t]{2}{*}{$\chi^{2}$} \\
\hline & Benin & Mali & & Benin & Burkina & Mali & & Mali & Niger & & & \\
\hline \multicolumn{13}{|c|}{ Have you noticed a change in the length of the seasons (rainy season, dry season...)? } \\
\hline Yes & 91.84 & 98.36 & 93.24 & 97.12 & 87.50 & 100.00 & 92.44 & 93.33 & 75.91 & 71.88 & 89.70 & \multirow[t]{2}{*}{$73.28 * \star \star$} \\
\hline No & 8.16 & 1.64 & 6.76 & 2.88 & 12.50 & 0.00 & 7.56 & 6.67 & 24.09 & 28.13 & 10.30 & \\
\hline \multicolumn{13}{|c|}{ Have you noticed a change in the length of the rainy season? } \\
\hline Increase & 12.24 & 1.64 & 5.41 & 9.62 & 0.00 & 0.00 & 0.00 & 3.33 & 2.19 & 1.56 & 3.59 & \multirow[t]{3}{*}{$90.73^{\star \star \star}$} \\
\hline Decrease & 73.47 & 77.05 & 76.35 & 87.50 & 62.50 & 100.00 & 78.99 & 63.33 & 74.45 & 67.19 & 76.85 & \\
\hline No change & 14.29 & 21.31 & 18.24 & 2.88 & 37.50 & 0.00 & 21.01 & 33.33 & 23.36 & 31.25 & 19.56 & \\
\hline \multicolumn{13}{|c|}{ Have you noticed a change in the length of the dry period? } \\
\hline Increase & 83.67 & 65.57 & 89.86 & 84.62 & 62.50 & 91.67 & 78.99 & 56.67 & 74.45 & 60.94 & 77.08 & \multirow[t]{3}{*}{$138.27 * * *$} \\
\hline Decrease & 0.00 & 0.00 & 2.03 & 12.50 & 0.00 & 0.00 & 0.00 & 1.67 & 0.00 & 6.25 & 2.43 & \\
\hline No change & 16.33 & 34.43 & 8.11 & 2.88 & 37.50 & 8.33 & 21.01 & 41.67 & 25.55 & 32.81 & 20.49 & \\
\hline \multicolumn{13}{|c|}{ Have you noticed a change in annual rainfall? } \\
\hline Increase & 34.69 & 3.28 & 27.03 & 11.54 & 1.79 & 0.00 & 0.00 & 1.67 & 13.14 & 40.63 & 13.54 & \multirow[t]{3}{*}{$168.96^{\star \star \star}$} \\
\hline Decrease & 46.94 & 88.52 & 58.11 & 83.65 & 67.86 & 93.33 & 78.15 & 71.67 & 71.53 & 56.25 & 71.64 & \\
\hline No change & 18.37 & 8.20 & 14.86 & 4.81 & 30.36 & 6.67 & 21.85 & 26.67 & 15.33 & 3.13 & 14.81 & \\
\hline \multicolumn{13}{|c|}{ Have you noticed a change in the maximum temperature? } \\
\hline Increase & 89.80 & 93.44 & 89.86 & 87.50 & 75.00 & 85.00 & 100.00 & 71.67 & 97.08 & 96.88 & 90.39 & \multirow[t]{3}{*}{$117.60 * \star \star$} \\
\hline Decrease & 2.04 & 0.00 & 2.03 & 9.62 & 0.00 & 6.67 & 0.00 & 1.67 & 0.73 & 0.00 & 2.31 & \\
\hline No change & 8.16 & 6.56 & 8.11 & 2.88 & 25.00 & 8.33 & 0.00 & 26.67 & 2.19 & 3.13 & 7.29 & \\
\hline
\end{tabular}

GZ= Guinean Zone; SGZ=Sudano-Guinean Zone; SZ= Sudanian Zone; SSZ=Sudano-Sahelian Zone; ShZ=Sahelian Zone; ShSaZ=SaheloSaharan Zone ; *** : significant at 0.001

Table 3. Dairy farmers' perception on impact of climate change

GZ= Guinean Zone; SGZ=Sudano-Guinean Zone; SZ= Sudanian Zone; SSZ=Sudano-Sahelian Zone; ShZ=Sahelian Zone; ShSaZ=SaheloSaharan Zone; $* \star *$ : significant at 0.001

\section{Figures}




\begin{tabular}{|c|c|c|c|c|c|c|c|c|c|c|c|c|}
\hline \multirow[t]{2}{*}{ Statements } & \multicolumn{2}{|l|}{$\mathrm{GZ}$} & \multirow{2}{*}{$\begin{array}{l}\text { SGZ } \\
\text { Benin }\end{array}$} & \multicolumn{3}{|l|}{ SZ } & \multirow{2}{*}{$\begin{array}{l}\text { SSZ } \\
\text { Burkina }\end{array}$} & \multicolumn{2}{|l|}{ ShZ } & \multirow{2}{*}{$\begin{array}{l}\text { ShSaZ } \\
\text { Niger }\end{array}$} & \multirow[t]{2}{*}{ Global } & \multirow[t]{2}{*}{$\chi^{2}$} \\
\hline & Benin & Mali & & Benin & Burkina & Mali & & Mali & Niger & & & \\
\hline \multicolumn{13}{|c|}{ What is the impact of climate change on herd size? } \\
\hline Increase & 89.80 & 45.90 & 59.31 & 38.24 & 71.43 & 11.67 & 51.69 & 36.67 & 28.68 & 20.00 & 44.48 & \multirow[t]{2}{*}{$131.44^{\star \star *}$} \\
\hline Decrease & 10.20 & 54.10 & 40.69 & 61.76 & 28.57 & 88.33 & 48.31 & 63.33 & 71.32 & 80.00 & 55.52 & \\
\hline \multicolumn{13}{|c|}{ What is the impact of climate change on livestock fertility? } \\
\hline Increase & 87.76 & 13.11 & 58.62 & 38.24 & 71.43 & 3.33 & 51.69 & 36.67 & 28.68 & 20.00 & 41.31 & \multirow[t]{2}{*}{$165.47 * \star \star$} \\
\hline Decrease & 12.24 & 86.89 & 41.38 & 61.76 & 28.57 & 96.67 & 48.31 & 63.33 & 71.32 & 80.00 & 58.69 & \\
\hline \multicolumn{13}{|c|}{ What is the impact of climate change on amount of milk produced? } \\
\hline Increase & 46.94 & 11.48 & 17.24 & 18.63 & 28.57 & 3.33 & 12.71 & 18.33 & 15.44 & 6.15 & 16.78 & \multirow[t]{2}{*}{$53.68 * \star \star$} \\
\hline Decrease & 53.06 & 88.52 & 82.76 & 81.37 & 71.43 & 96.67 & 87.29 & 81.67 & 84.56 & 93.85 & 83.22 & \\
\hline \multicolumn{13}{|c|}{ What is the impact of climate change on fodder availability? } \\
\hline Increase & 4.08 & 1.64 & 4.14 & 1.96 & 21.43 & 5.00 & 2.54 & 3.33 & 8.82 & 4.62 & 5.40 & \multirow[t]{2}{*}{$38.44 * \star \star$} \\
\hline Decrease & 95.92 & 98.36 & 95.86 & 98.04 & 78.57 & 95.00 & 97.46 & 96.67 & 91.18 & 95.38 & 94.60 & \\
\hline \multicolumn{13}{|c|}{ What is the impact of climate change on microbial proliferation and rapid milk fermentation? } \\
\hline Increase & 87.76 & 86.89 & 86.90 & 83.33 & 85.71 & 86.67 & 94.92 & 66.67 & 94.85 & 90.77 & 87.68 & \multirow[t]{2}{*}{$39.45^{\star \star \star}$} \\
\hline Decrease & 12.24 & 13.11 & 13.10 & 16.67 & 14.29 & 13.33 & 5.08 & 33.33 & 5.15 & 9.23 & 12.32 & \\
\hline \multicolumn{13}{|c|}{ What is the impact of climate change on milk quality? } \\
\hline Increase & 0.00 & 8.20 & 8.97 & 3.92 & 5.36 & 1.67 & 0.00 & 40.00 & 2.21 & 0.00 & 6.22 & \multirow[t]{2}{*}{$141.91^{\star * *}$} \\
\hline Decrease & 100.00 & 91.80 & 91.03 & 96.08 & 94.64 & 98.33 & 100.00 & 60.00 & 97.79 & 100.00 & 93.78 & \\
\hline \multicolumn{13}{|c|}{ What is the impact of climate change on the conservation of fresh milk? } \\
\hline Increase & 4.08 & 0.00 & 4.14 & 5.88 & 5.36 & 1.67 & 0.85 & 0.00 & 1.47 & 0.00 & 2.46 & \multirow[t]{2}{*}{$15.83^{\star \star \star}$} \\
\hline Decrease & 95.92 & 100.00 & 95.86 & 94.12 & 94.64 & 98.33 & 99.15 & 100.00 & 98.53 & 100.00 & 97.54 & \\
\hline
\end{tabular}




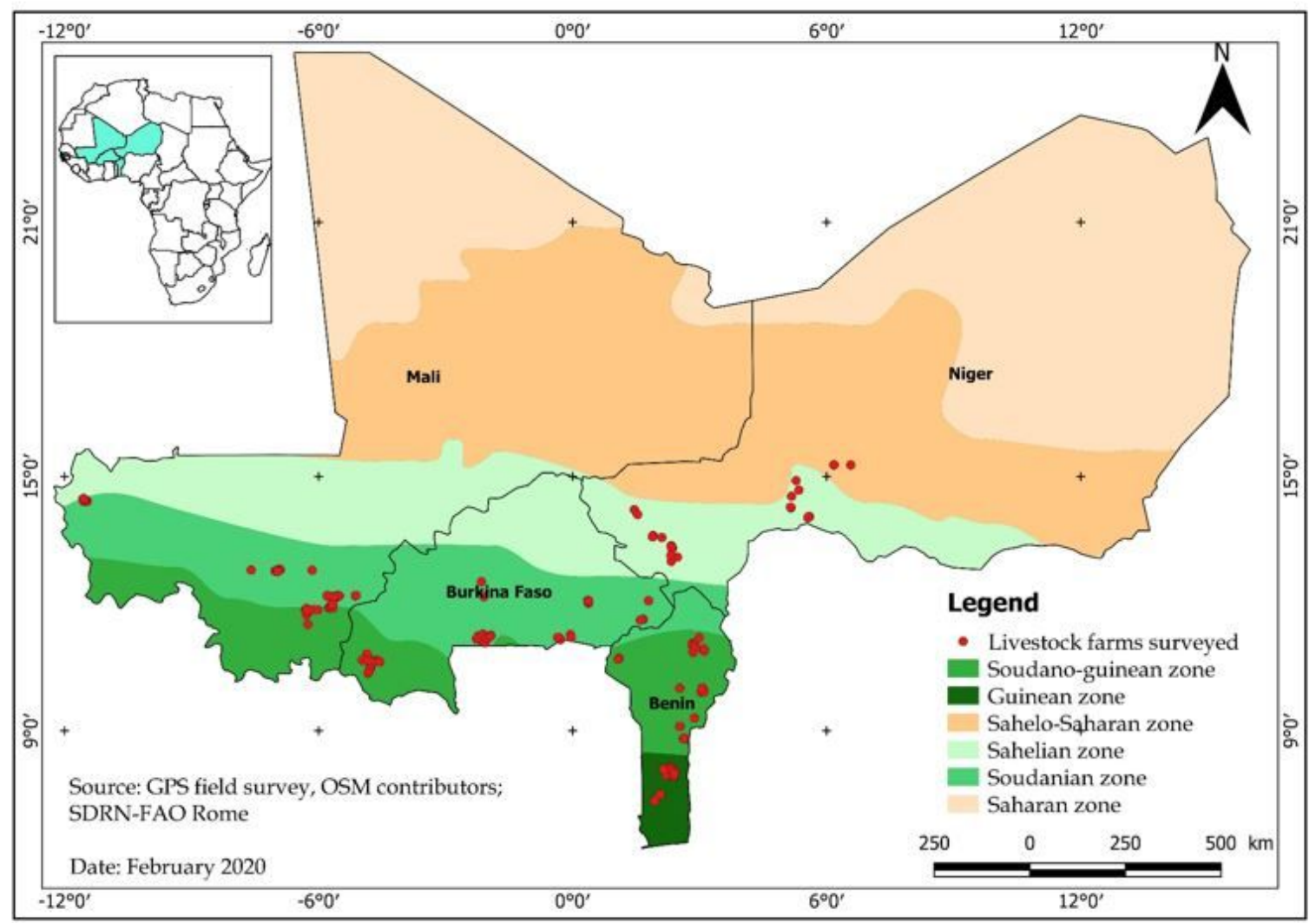

\section{Figure 1}

Study areas Note: The designations employed and the presentation of the material on this map do not imply the expression of any opinion whatsoever on the part of Research Square concerning the legal status of any country, territory, city or area or of its authorities, or concerning the delimitation of its frontiers or boundaries. This map has been provided by the authors.

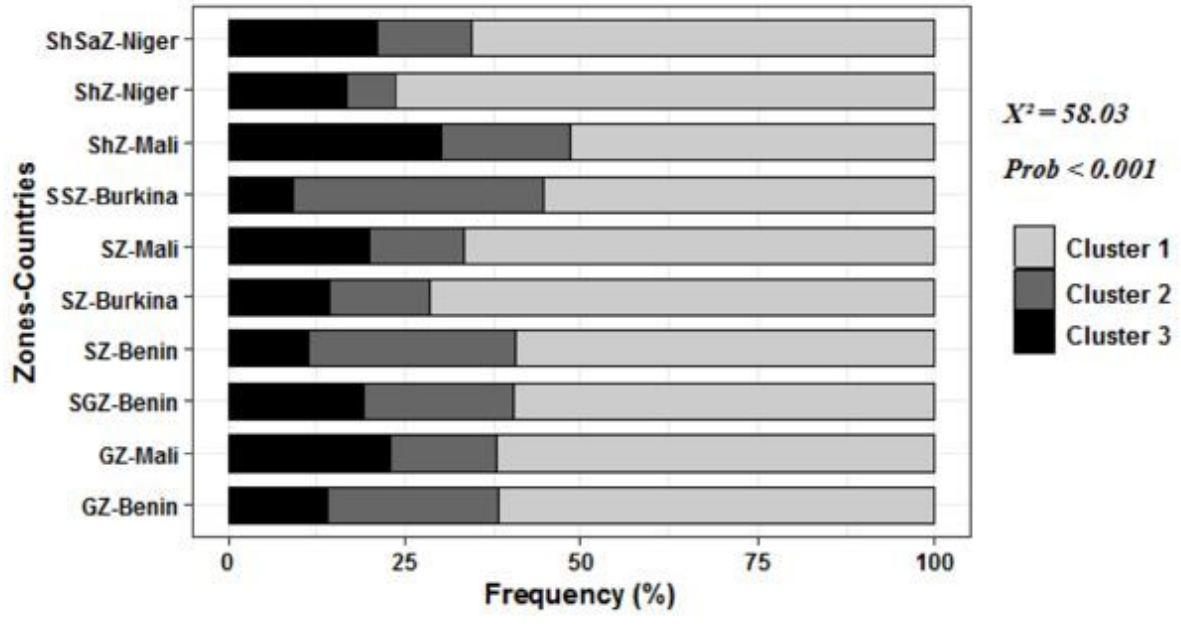

\section{Figure 2}

Relation between clusters of dairy production systems, climatic zones and countries GZ= Guinean Zone; SGZ=Sudano-Guinean Zone; SZ= Sudanian Zone; SSZ=Sudano-Sahelian Zone; ShZ=Sahelian Zone; ShSaZ=Sahelo-Saharan Zone 


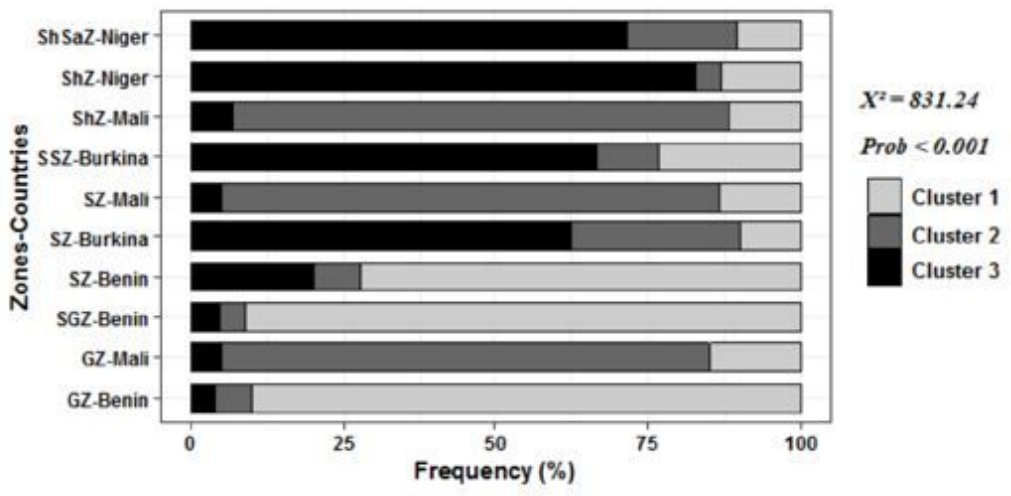

\section{Figure 3}

Relation between cluster of adaptation system, climatic zones and countries GZ= Guinean Zone; SGZ=Sudano-Guinean Zone; SZ= Sudanian Zone; SSZ=Sudano-Sahelian Zone; ShZ=Sahelian Zone; ShSaZ=Sahelo-Saharan Zone
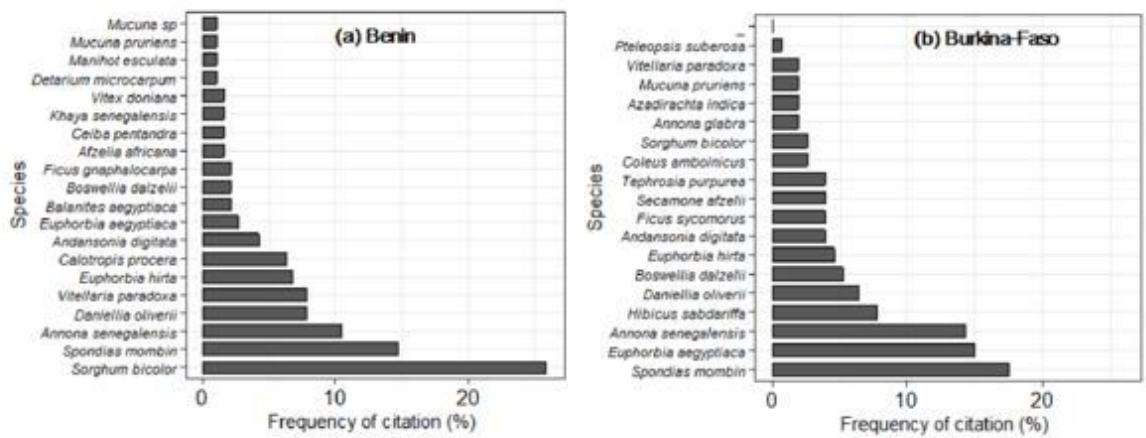

$\mathbf{A}$
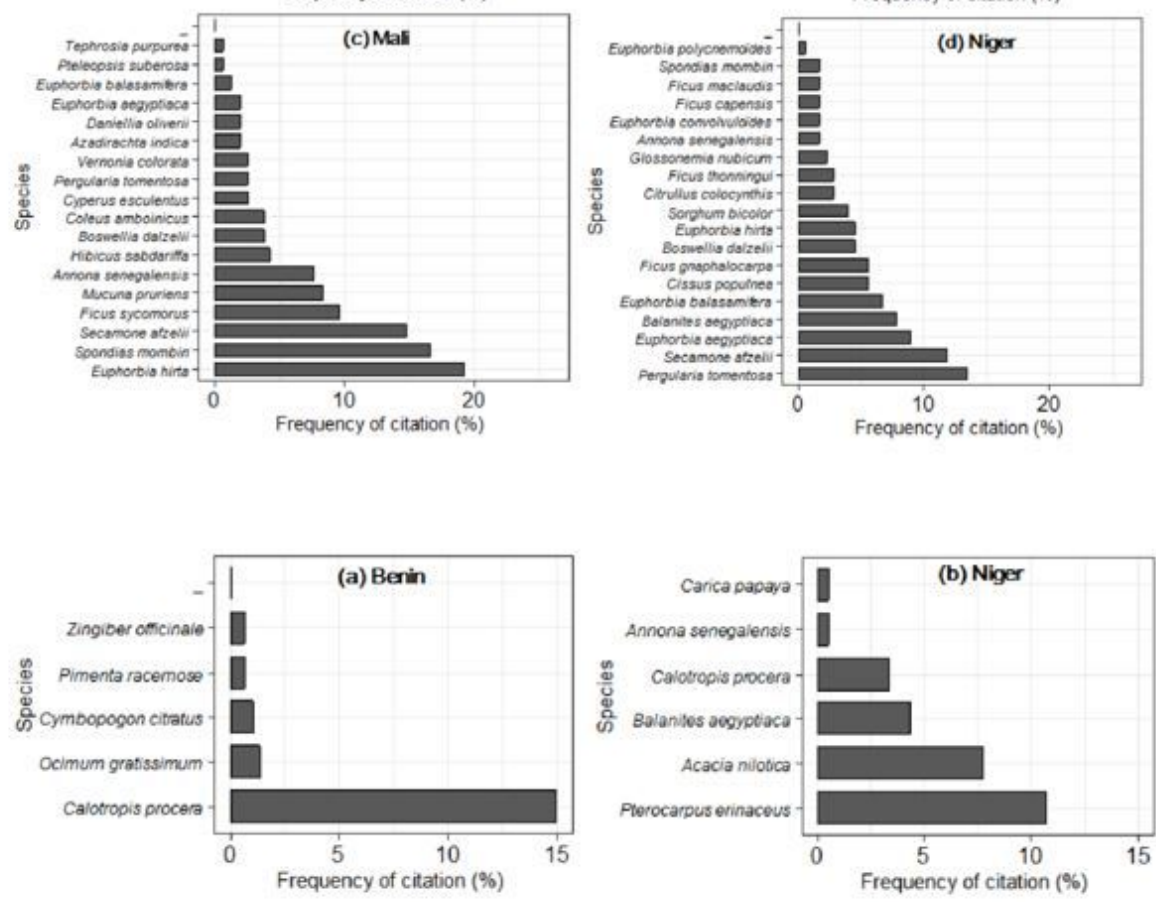

B

\section{Figure 4}

Galactogenics plants used to feed cows to improve milk production (A) and plants used to conserve milk against fermentation (B) 


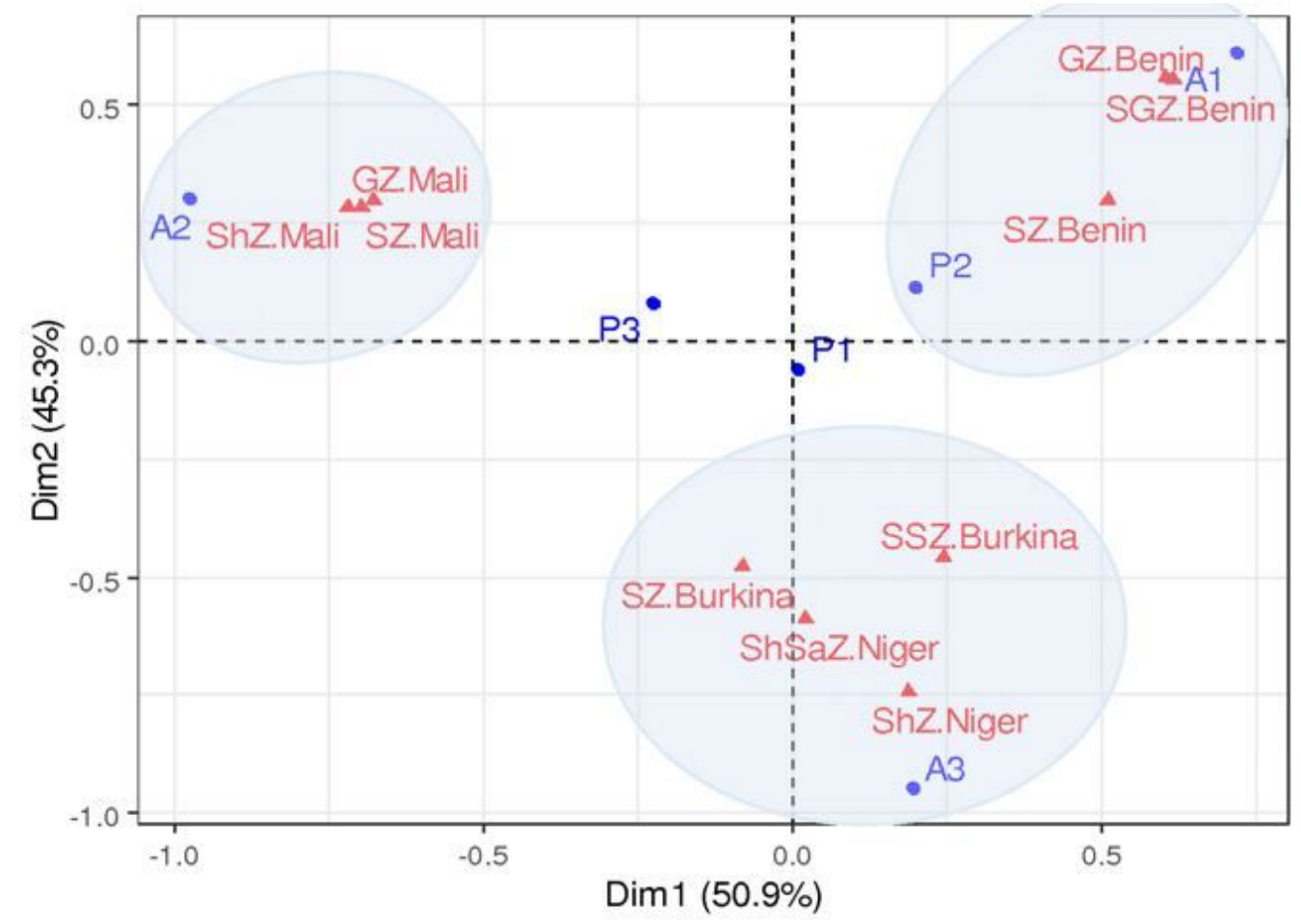

\section{Figure 5}

Correspondence factor analysis on the relationship between production and adaptation systems $\mathrm{P}=$ Production system; $\mathrm{A}=\mathrm{Adaptation}$ system; GZ= Guinean Zone; SGZ=Sudano-Guinean Zone; SZ= Sudanian Zone; SSZ=Sudano-Sahelian Zone; ShZ=Sahelian Zone; ShSaZ=Sahelo-Saharan Zone 